\title{
ОСОБЛИВОСТІ ВИЖИВАННЯ ТА РОЗВИТКУ ХЛІБНОГО ЖУКА-КУЗЬКИ (ANISOPLIA AUSTRIACA H.) НА ПШЕНИЦІ ОЗИМІЙ В ЛІСОСТЕПУ УКРАЇНИ
}

\author{
B. В. САХНЕНКО, кандидат сільськогосподарсьКИХ наук \\ Д. В. САХНЕНКО, аспірант* \\ Національний університет біоресурсів і природокористування України \\ E-mail:Sakhneno@gmail.com
}

\begin{abstract}
Анотація. Висвітлено особливості розмноження, розвитку та виживання твердокрилих фітофрагів на посівах пшенищі озимої з використанням вдосконалених технологій моніторингу цих икідників в Лісостепу України. Уточнено особливості біології та екології хлібного жука-кузьки (Anisoplia Austriaca Н.), що належить до ряду Твердокрилі - Coleoptera, родини Пластинчастовусі Scarabaeidae, на сівозмінах пшениці озимої в регіонах досліджень. Встановлено, що популяції основних видів твердокрилих икідників, які формуються восени та влітку проходять за циклічними коливаннями чисельності.

Спалахи чисельності хлібного-жука кузьки повторюються через різні проміжки часу, вони синхронізовані з циклами погоди, клімату, урожайності зернових колосових культур і сонячної активності, що чинить як прямий, так і опосередкований вплив на динаміку біосрери, агроекосистем та популяції, які їх заселяють.

Характерно, що різке коливання погоди, виявилось оптимальним для розвитку й поширення цих видів шкідників генеративних органів пшениці озимої та інших зернових колосових культур у Лісостепу України.
\end{abstract}

Ключові слова: пшениця озима, хлібний жук-кузька, моніторинг, пошкодженість, заходи захисту, розмноження, контроль чисельності шкідників

\section{Актуальність дослідження.}

У 2000 - 2017 рр. у системах захисту пшениці озимої від твердокрилих шкідників дослідження моніторингу чисельності комплексу шкідливих видів комах і з'ясування причин їхнього масового розмноження та поширення має особливе значення для госпо- дарств усіх форм власності (Доля М. М., Покозій Й. Т., Мамчур Р. М., 2004)

3 метою визначення відсотку ураженості рослин пшениці озимої шкідниками та розробки подальших заходів захисту від шкідливого ентомокомплексу в Лісостепу України постає питання про проведення моніторингу та визначення наявності по-

\footnotetext{
* Науковий керівник - доктор сільськогосподарських наук, професор М. М. Доля
} 
шкодження рослин пшениці озимої хлібним жуком-кузькою та іншими шкідниками.

Мета досліджень - провести моніторинг та визначити динаміку чисельності хлібного жука-кузьки (Anisoplia Austriaca H.) в посівах пшениці озимої, що вирощуються за новими технологіями.

\section{Матеріали та методи дослідження.}

Експерименти виконували в Агрономічній дослідній станції НУБіП (Васильківський район Київської області) та в навчальному науково-виробничому центрі «Великообухівське» (Миргородський район Полтавської області), маршрутні обстеження проведені на тимчасових виробничих дослідах, закладених у Вінницькій, Тернопільській, Хмельницькій, Чернігівській, Черкаській та інших областях. У дослідженнях використовували польові загальноприйняті польові та лабораторні методи досліджень, а також розрахунково-порівняльний та математично-статистичний аналізи експериментальних даних (Доля М. М., Покозій Й. Т., Мамчур Р. М., 2004; Покозій Й. Т., Писаренко В.М., Довгань С. В., Доля М. М., Мамчур Р. М., Бондарева Л.М., Пасічник Л. П., 2010), статистичну обробку результатів досліджень - за А. В. Кулєшовим (Кулєшов А.В., Білик М. О., Довгань С. В., 2011).

Під час проведення обліків чисельності шкідників визначали два взаємопов'язані показники - облік стадіального розповсюдження та облік щільності поселень, або чисельності в заселених стадіях.

Розповсюдження, або ступінь заселення пшениці озимої та інших угідь, виражали у відсотках заселе- них гектарів, рослин або органів, проб відносно обстежених і вираховували за формулою:

$$
P=\frac{\sum \cdot a}{\sum \cdot A} \cdot 100,
$$

де $\mathrm{P}$ - розповсюдження шкідника (\% заселених площ);

$$
\begin{aligned}
& \sum \cdot a-\text { сума заселених площ, га; } \\
& \sum \cdot A-\text { загальна сума обстеже- }
\end{aligned}
$$
них площ, га.

Поряд із заселенням угідь враховували чисельність виду в кожному типі стацій, що теж характеризує фазу динаміки популяції.

Для характеристики середньої чисельності шкідника визначали середньозважений показник чисельності (Чс) по відношенню до заселеної площі:

$$
\Psi_{c}=\frac{\sum(u \cdot a)}{\sum a},
$$

де $\sum(\varphi \cdot a)$ - сума добутків середньої чисельності шкідника (ч) на відповідну заселену площу (а);

$\sum a$ - сума заселених площ, га.

За різного рівня чисельності окремого виду шкідника в роки спостережень і зв'язані з ним різної заселеності посівів пшениці озимої загальна фактична територія, що піддавалась обстеженню, формувалася у базових господарствах і областях Лісостепу України.

\section{Результати досліджень та їх обговорення.}

У 2001 - 2018 рр. встановлено, що в сучасних структурах польових сівозмін під час вирощування пшениці 
озимої особливого значення набуває застосування моніторингу сезонної динаміки чисельності як грунтових, так і внутрішньостеблових шкідників пшениці озимої на усіх етапах росту й розвитку культурних рослин. Особливість їхньої біології, а також показники міграції в грунті й на поверхні, під час появи сходів цієї культури є основою щодо густоти посівів й ефективності систем землеробства.

Характерно, що в роки спостережень літ жуків тривав із кінця травня до початку серпня, але в окремі роки ці строки коливалися в межах двох тижнів; масовий літ - 311 червня до 25 липня. Жуки були активні у спекотні сонячні дні, живилися на колоссі пшениці озимої. Через два тижні після виходу починалося відкладання самицями яєць, для чого самка заривалася в грунт на глибину $10-15$ см і відкладала яйця невеликими купками, за 2-3 прийоми по 30-40 шт. Через три тижні 3 яєць виходили личинки, що живились перегноєм і дрібними корінцями різних рослин, у тому числі культурних, личинки старших віків - переважно корінням. Восени вони переходили в грунт на глибину 30-80 см, а навесні знову піднімалися до поверхні. Упродовж літа линяли двічі.

Заляльковування відбувалося в грунтових колисочках на глибині 1015 см. У стадії лялечки перебували близько двох тижнів, після чого виходили імаго. У зв'язку з дворічним циклом розвитку через рік спостерігаються льотні роки. Чисельність жука-кузьки знижували нематоди, грибні та бактеріальні захворювання; на личинках паразитувала тахіна Microphthalma europea Egg.

Установлено, що хлібні жуки, зокрема хлібний жук-кузька, розмножувались із циклічністю 6 років, і в областях із порівняно невисокою чисельністю личинок до 0,5 екз. $\mathrm{M}^{2}$. Цей фітофаг завдавав певної шкоди в роки інтенсивної сонячної інсоляції, тоді як в інші періоди цей фітофаг не розвивався на сходах пшениці озимої. Характерно, що в окремих областях регіону досліджень кількість личинок хлібних жуків місцями становила 2,7 екз. $\mathbf{M}^{2}$, а за протруєння насіння інсектицидами чисельність личинок хлібних жуків не перевищувала 0,5 екз. $\backslash \mathbf{M}^{2}$ (рис. 1).

Водночас сезонна динаміка популяцій імаго хлібного жука-кузьки також формувалася циклічно. Достовірне зниження ступеня заселення пшениці озимої хлібним жуком спостережене в 2006, 2007 роках, а порівняно високою заселеністю посівів пшениці озимої хлібним жуком помічені 2001 - 2005, 2009, 2012, 2015 і 2017 роки. Це свідчить про важливість контролю чисельності хлібного жука-кузьки із застосуванням інсектицидів як для протруєння насіння, так i для обприскування пшениці озимої в період колосіння - наливу зерна (рис. 2).

Особливістю моніторингу хлібних жуків $є$ оцінка інтенсивності їхньої міграції в областях спостережень під час застосування спеціальних захисних заходів.

Зокрема, під час протруєння насіння захисно-стимулюючими сумішами із застосуванням інсектицидів контактно-системної дії кількість як личинок, так і імаго хлібного жука-кузьки, а також показники заселених площ цим фітофагом зменшилися в 7-8 разів у 2013, 2015-2018 роках порівняно з $2008-2012$ pр.

Водночас у 2006, 2007 роках хлібні жуки практично не заселяли пшеницю озиму, що свідчить про основне значення коливань погоди 

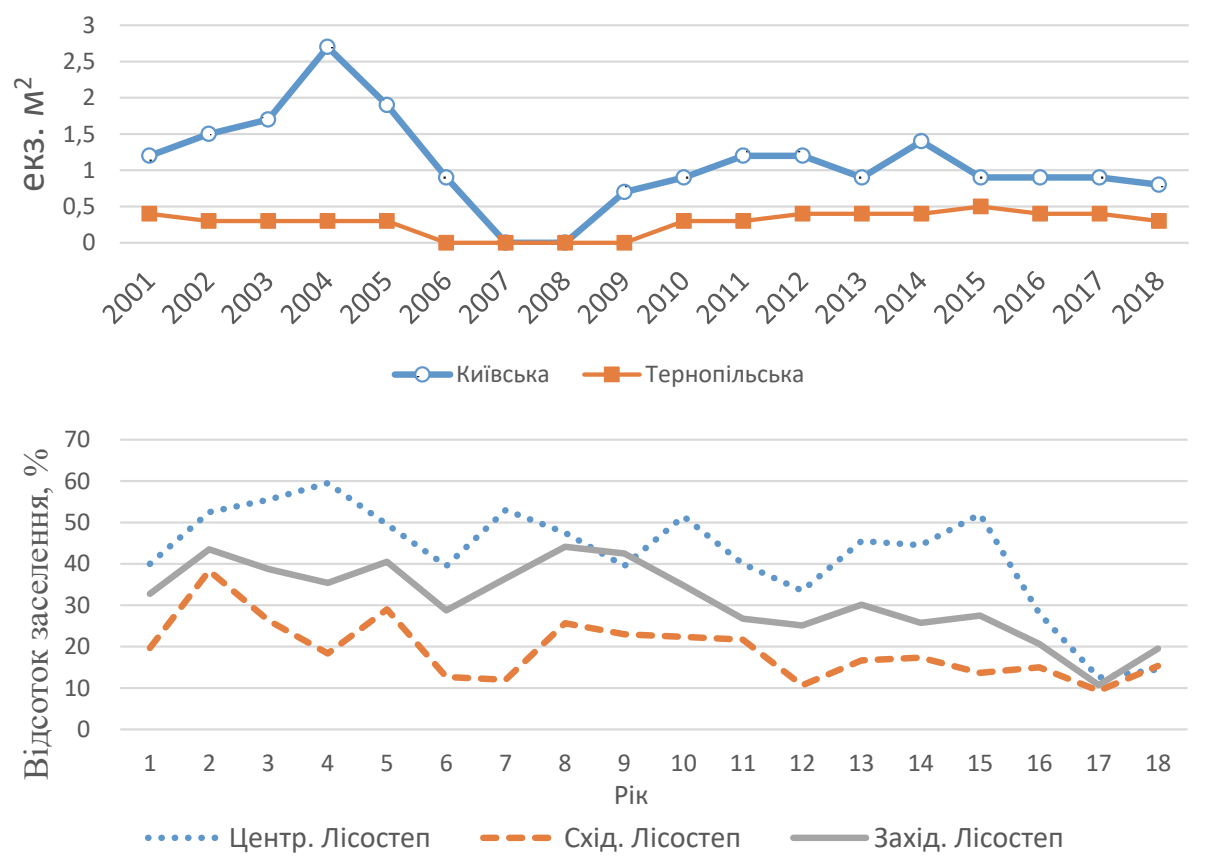

\section{Рис.1 Чисельність личинок хлібних жуків на посівах пшениці озимої в Лісостепу України, у середньому за 2001-2018 рр.}

у виживанні імаго й личинок, а також впливу на них систем захисних заходів, що підтверджує важливість контролю хлібних жуків на посівах пшениці із застосуванням моделей прогнозу кількісних показників формувань популяції в регіоні спостережень (рис. 3).

У регіоні досліджень хлібні жуки заселяли пшеницю озиму на назначених площах у Полтавській, Харківській, Київській областях із достовірно меншими їх кількостями в Хмельницькій та Вінницькій областях. У Тернопільській області ці фітофаги інтенсивно заселяли посіви у 2010, 2012, 2015 роках порівняно 3 іншими роками досліджень. У 2006-2007 pр. ці фітофаги не виявлені на посівах пшениці озимої в усіх базових господарствах спосте- режень, що пов'язано 3 комплексом абіотичних та інших чинників.

Так, у відносно посушливі роки, якими виявились 2001, 2007, 2015, 2016, 2018, личинки хлібних жуків мігрували в порівняно глибокі шари грунту до $3 \mathrm{~cm}$ в осінній період i практично не пошкоджували сходів пшениці озимої. Однак у 2003, 2006, 2010 і 2014 роках ці фітофаги завдавали відчутної шкоди сходам пшениці озимої і викликали зменшення числа культурних рослин на 7-11\% порівняно 3 іншими роками досліджень.

Отже, важливість урахування особливостей як розвитку, так і розмноження личинок хлібних жуків, зокрема, під час моделювання ступеня заселення ними пшениці озимої, сприяє оптимізації використання спе- 


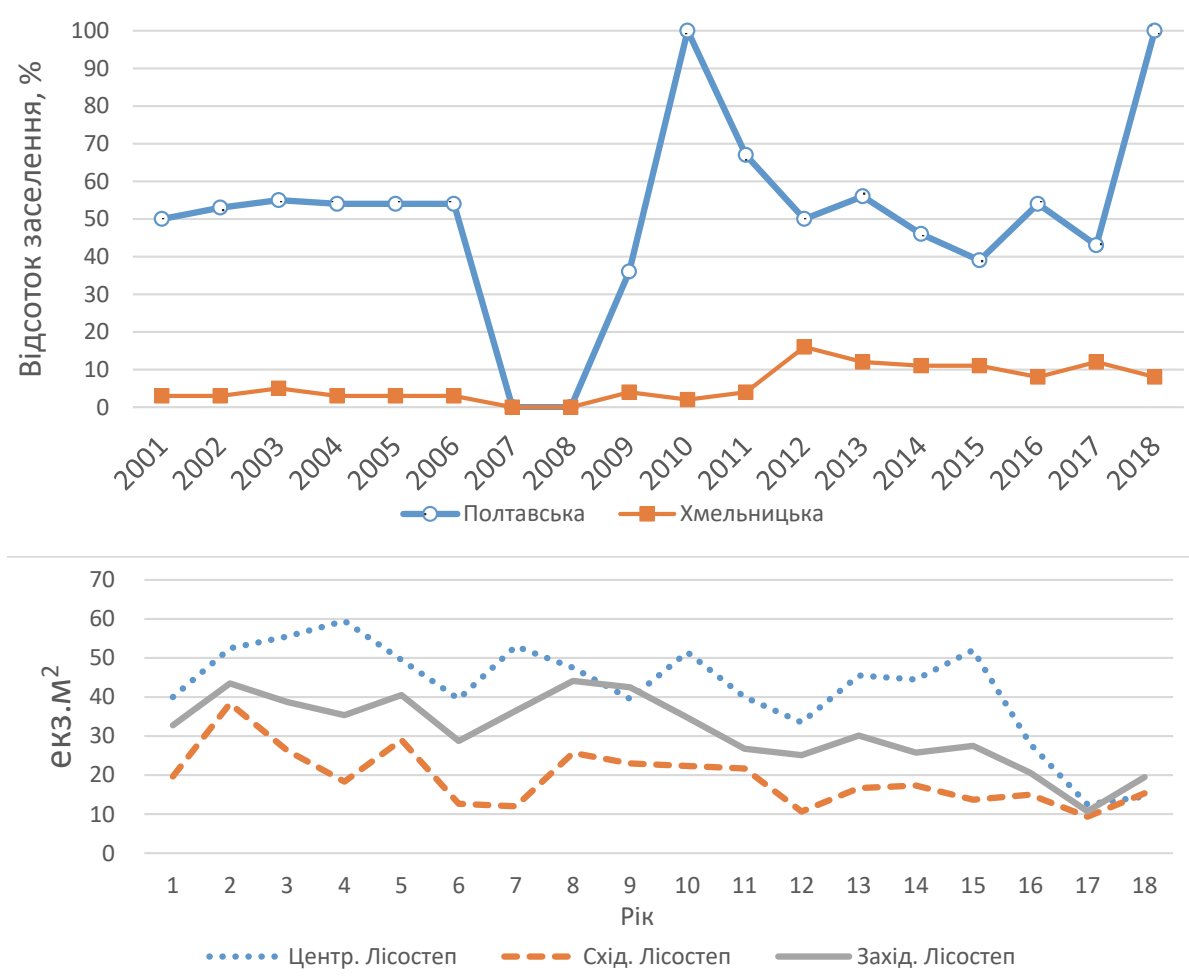

Рис.2 Заселеність посівів пшениці озимої імаго хлібного жука-кузьки в Лісостепу України, у середньому 2001-2018 pp.

ціальних препаратів для протруєння насіння інсектицидами. Заслуговує на особливу увагу фенологія хлібних жуків, а саме прискорення на 5-11 діб розвитку личинок та лялечок цих фітофагів, що помічено у 2007, 2015 і 2018 роках. Важливим є і показник співвідношення загальної чисельності грунтових фітофагів, яке в структурі виявлених грунтових шкідників на 32-39 \% представлене личинками хлібних жуків, а в структурі останніх на $62-75$ \% превалювали личинки хлібного жука-кузьки.

Між тим заслуговує на увагу особливість міграцій хлібних жуків залежно від строків достигання й періоду вегетації пшениці озимої. Так, на порівняно пізніх сортах ці фітофа- ги інтенсивно розмножувались і достовірно спричиняли зменшення як кількісних, так і якісних показників зерна в колосі порівняно 3 ранньота середньостиглими сортами. Це свідчить про важливість додаткового живлення імаго на колосі пшениці озимої, що потрібно враховувати в структурі районованих та перспективних сортів і технологіях вирощування цієї культури в Лісостепу України. Виявлено, що в усіх областях превалює хлібний жук-кузька, який інтенсивно розмножується за сучасних систем землеробства (зокрема, на різних фонах і технологіях ведення рослинництва) та впливає на показники розвитку й отримання валових зборів урожаю зерна. 

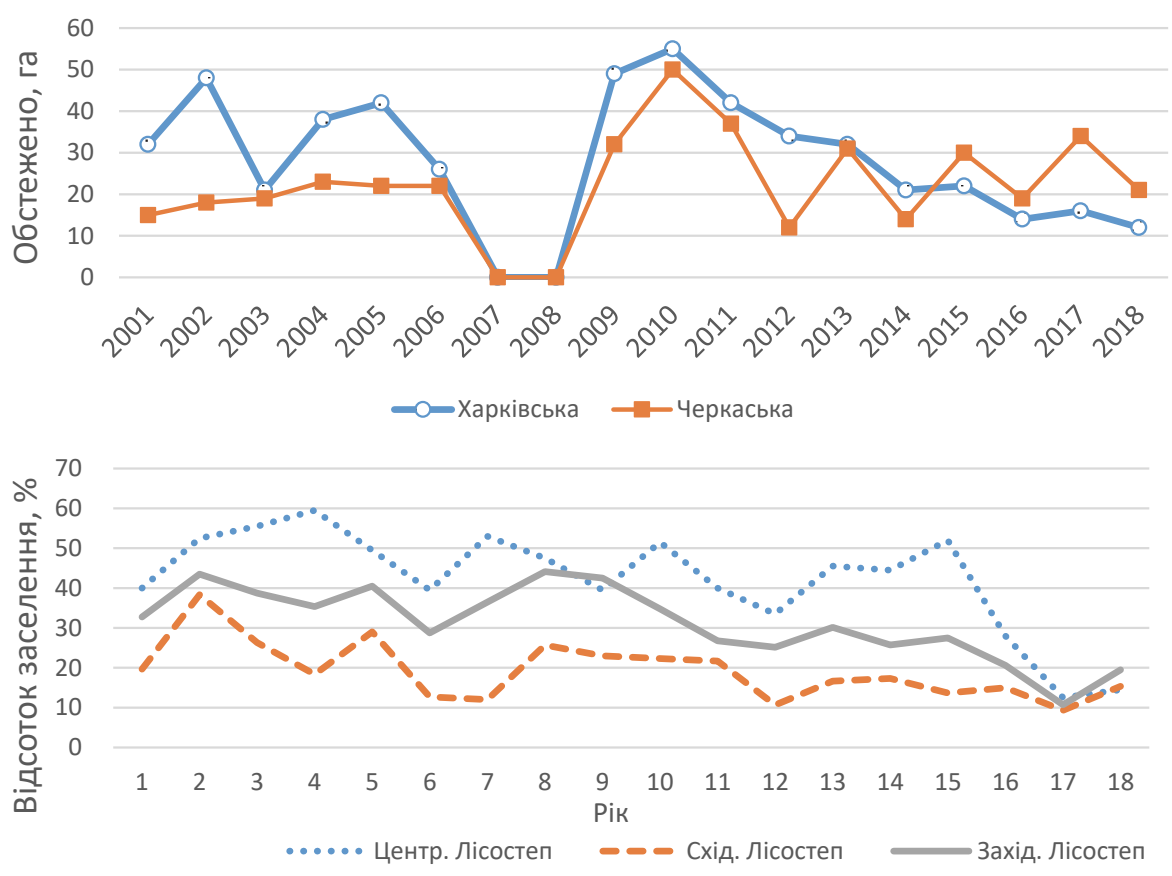

Рис.3. Моніторинг хлібних жуків на посівах пшениці озимої в Лісостепу України, у середньому 2001-2018 рр.

\section{Висновки та перспективи.}

Таким чином, у сучасних умовах вирощування пшениці озимої особливого значення набувають розроблення і впровадження у виробництво моделей багаторічного прогнозу заселення посівів пшениці хлібними жуками 3 урахуванням коливань погоди, а також динаміки чисельності фітофагів у попередні роки спостережень. Це сприятиме оптимізації систем захисту пшениці від хлібних жуків із застосовуванням сучасних засобів захисту сходів і колосу пшениці від основних стадій розвитку хлібних жуків.

Моніторинг розвитку, розмноження та поширення хлібних жуків 3 уточненням механізмів формувань популяцій сприяє оптимізації норм i строків застосувань комплексу заходів захисту пшениці озимої від фітофагів у господарствах усіх форм власності.

\section{References}

1. Dolya, M. M., Pokoziy, Y. T. \& Mamchur R. M. (2004). Fitosanitarnyy monitorynh [Phytosanitary monitoring]. (p. 249), NNTSIAE. [in Ukrainian]

2. Pokosy, Y. T., Pisarenko, V. M., Dovgan, S.V., Dolya, M. M., Mamchur, R. M., Bondareva, L. M. \& Pasichnik L.P. (2010). Monitorynh shkidnykiv silskohospodarskykh kultur [Monitoring of pests of agricultural crops]. (p. 223), Ahrarna osvita. [in Ukrainian]

3. Kulyeshov, A. V., Bilyk, M. O., Dovhan, S. V. (2011). Fitosanitarnyy monitorynh i prohnoz. [Phytosanitary monitoring and forecast]. (p.608), Espada. [in Ukrainian]

4. Havrylyuk, M. (2009). Osoblyvosti zakhystu sil's'kohospodars'kykh kul'tur 
vid shkidnykiv i khvorob. [Features of protection of agricultural crops from pests and diseases.] (p.12). Ahrarnyy tyzhden' Ukrayiny. [in Ukrainian]

5. Oliveira, C., Auad, A., Mendes, S. \& Frizzas, M. (2014). Crop losses and the economic impact of insect pests on Brazilian agriculture. (pp. 50-54), Crop Protection. [in English]

6. Milosavljevic, I., Esser \&, Aaron, D. (2016). Effects of environmental and agronomic factors on soil-dwelling pest communities in cereal crops. Agriculture Ecosystems \& environment, 192-198 [in English]

\section{V. Sakhnenko, D. V. Sakhnenko (2019). FEATURES OF THE SURVIVAL AND DEVELOPMENT OF THE GRAIN-BEETLE BEETLE (ANISOPLIA AUSTRIACA H.) ON WINTER WHEAT IN THE FOREST-STEPPE OF UKRAINE.}

PLANT AND SOIL SCIENCE, 10(3): 63-69. https://doi.org/10.31548/agr2019.03.063

Abstract. The features of reproduction, development and survival of beetles of phytophages on winter wheat crops using advanced monitoring technologies of these pests in the forest-steppe of Ukraine are highlighted. Specific features of the biology and ecology of the grain beetle Anisoplia H. (Anisoplia Austriaca H.), which is included in the number of beetles - Coleoptera, lamellar families - Scarabaeidae, on the rotation of winter wheat in research regions. It has been established that the populations of the main species of beetles that form in the fall and summer pass through cyclical fluctuations in numbers.

The outbreaks of the grain-beetle Kuz'ka repeat at different intervals, they are synchronized with the cycles of weather, climate, the yield of cereal crops and solar activity, and have a direct and indirect effect on the dynamics of the biosphere, agroecosystems and populations, they are populated.

It is characteristic that the sharp fluctuation of the weather turned out to be optimal for the development and distribution of these types of pests of the generative organs of winter wheat and other cereal crops in the Forest-Steppe of Ukraine.

Keywords: winter wheat, grain beetle, monitoring, damage, protection measures, reproduction, control of the number of pests 